\title{
DESCRIPTIONS OF THE NESTS OF \\ PSEUDOCHARTERGUS FUSCATUS AND STELOPOLYBIA TESTACEA, WITH A NOTE ON A PARASITE OF S. TESTACEA (HYMENOPTERA, VESPIDAE).*
}

\author{
By Robert L. Jeanne \\ The Biological Laboratories, Harvard University \\ Cambridge, Mass.
}

The nest built by a colony of wasps is the tangible product of complex behavior patterns which have evolved in response to a variety of factors. Since the nest is a solid object which remains after the colony has gone, it provides a direct means of gaining insight into some of these factors. The remarkable architectural diversity of nests, especially among tropical species, suggests that the factors in question are many and varied.

Beyond their importance in studies of the adaptations of individual species, nests must be taken into consideration in studies of the phylogeny of the social vespids. Richards and Richards (195 I) point out that the details of behavior as well as morphology must be carefully studied in deducing phylogenetic relations of each group so that those characters selected will combine to give the most consistent classification. Henri de Saussure (1853-8) was the first to classify nests of social wasps according to their structure. Adolph Ducke, to whom we are indebted for much of what we know about neotropical social wasps, attempted to construct a phylogeny of the Vespidae based on Saussure's classification (Ducke, I9I4), but his success was limited by inadequate taxonomic knowledge of the wasps themselves, and a lack of knowledge of the details of nest-building behavior. Ducke also made no attempt to understand the adaptive functions of the various features of nest structure. Though a great deal has been accomplished since Ducke's time, especially through the work of Bequaert and of the Richardses, we still have much to learn before we can hope to understand the evolution of nest structure in this family. The nests of roughly $30 \%$ of the species of neotropical polistine wasps (exclusive of the genera Polistes and Mischocyttarus) remain completely unknown, and many of the descriptions that do exist are cursory and note only general architecture. Almost nothing is known of the behavior associated with the details of nest-building.

\footnotetext{
*Manuscript received by the editor February 20, 1970.
} 


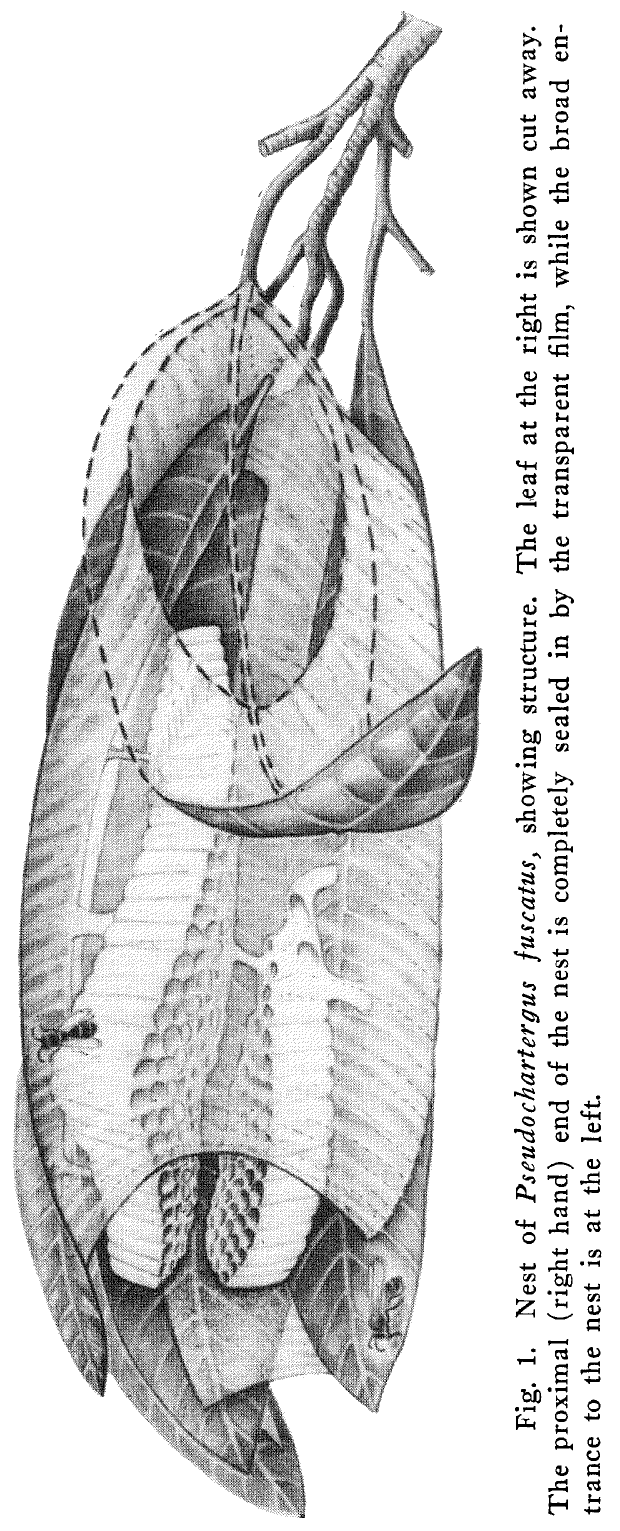


Pseudochartergus fuscatus has been recorded only from the Amazon basin. Its nest is remarkable in that it is enclosed in a transparent envelope. This feature is shared with the congener $P$. chartergoides. $P$. fuscatus also has cells that open upward, an extremely rare trait in the Vespidae. The nest of Stelopolybia testacea, a species that ranges from northern South America to Bolivia, is very similar in structure to those of $S$. pallipes and $\mathcal{S}$. cajennensis. The nest described here was unique, however, in having been constructed in a relatively exposed site, on the underside of a palm spathe. Moreover, it was one of the largest and most populous nests of any social vespid ever taken in the American equatorial tropics.

A sample of the adult population of each nest has been deposited in the collection of the Museum of Comparative Zoology at Harvard University. The field numbers are $7 \mathrm{I}$ and 265 for the colonies of $P$. fuscatus and $S$. testacea, respectively. One specimen of the parasite of $S$. testacea has also been placed in the MCZ collection.

\section{Pseudochartergus fuscatus}

I found a single colony on November 30,1967 , in the Utinga district on the outskirts of Belém, Pará, Brazil $\left(\mathrm{I}^{\circ} 27^{\prime} \mathrm{S}, 4_{4} 8^{\circ} 29^{\prime} \mathrm{W}\right)$. The nest was located in an isolated tree growing in marshy soil at the upper end of an arm of a reservoir. The trunk of the tree would stand in shallow water during the rainy season (January through June), when the reservoir is full. The tree was about eight meters tall and twenty meters distant from tall second-growth forest, which surrounded it on three sides. The nest was built in the thick foliage at the end of a small branch about four meters from the ground.

The adult wasps were very timid, and the slight shaking of the nest as I collected it caused them all to retreat inside. Even more violent shaking after the branch was clipped would not bring them out to defend their brood. Only when the colony was placed inside

Fig. 2. Nest of Pseudochartergus fuscatus. The combs are visible through the entrance. The parallel ridges in the broad sheet of transparent film to the right of the combs probably mark boundaries between successive additions of the secretion. Slightly larger than natural size.

Fig. 3. Upper comb of Pseudochartergus fuscatus nest, showing brood distribution. The two dark cells just above the five pupae near the center contain eggs of the third generation of brood. Large larvae are visible in surrounding cells. Some of the cells among the outer pupae are empty but still have fragments of cocoon attached to them; these are cells from which adults emerged after the nest was collected. $11 / 2$ times natural size. 

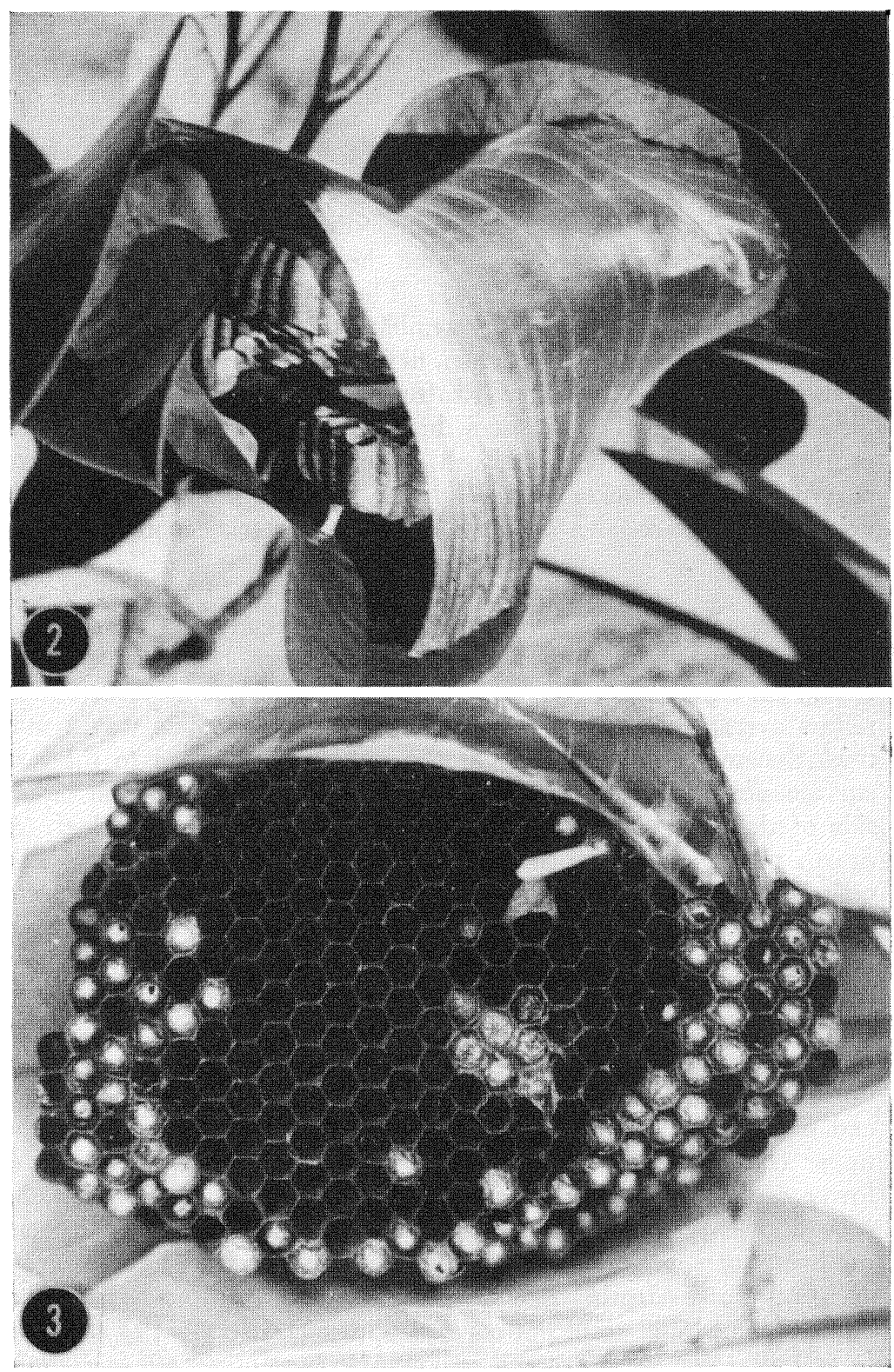
a plastic bag with cyanide did the adults fly from the nest in a sudden burst. All of the 230 adults present were females. Since the nest was collected during the day there were probably more out foraging.

The six leaves surrounding the nest were joined together with large amounts of a dry, transparent film, the resulting structure forming a watertight envelope around the nest, with a broad opening at the distal end (Figs. I \& 2). The film, probably a secretion produced by the adult wasps, resembled thick cellophane in that it was quite pliable, crackled when flexed and tore much like cellophane. If wetted with water it softened but retained its form. The film never covered leaf surfaces, but did bridge gaps of up to four centimeters between leaves. Each sheet of the film had a series of curved ridges of thicker material; these probably marked the boundaries between successive applications of the material to the growing edge (Fig. 2).

The nest consisted of two horizontal combs constructed of a finetextured carton. The upper comb was the larger, being $4.5 \mathrm{~cm}$ wide by $6.5 \mathrm{~cm}$ long. It was suspended below a single leaf by three carton pillars averaging $5 \mathrm{~mm}$ in length. The largest of these was $3 \mathrm{~mm}$ thick, located near the center of the comb and attached to the leaf surface next to the midrib. The other two pillars, one on either side of the central one, were attached to the midrib of the leaf. A fourth pillar joined one side of the comb to an adjacent leaf. The cells of this comb opened downward. The second comb $(2.0 \mathrm{~cm}$ wide by $4.0 \mathrm{~cm}$ long) was directly below the upper one and fixed to the dorsal surface of a smaller leaf by five pillars $5 \mathrm{~mm}$ long. The cells of this comb opened upward, though there were several irregularly-placed cells which opened to one side (Fig. I). The two combs were joined by a single pillar issuing from the face of the upper comb near its center and attaching directly to a pillar at one end of the lower comb. A second pillar connected the face of the upper comb directly to the surface of the lower leaf next to the lower comb. The pillars were constructed entirely of carton. The cells of each comb averaged $3.0 \mathrm{~mm}$ in diameter (measured from midpoints of opposite walls). Cells which had produced adults averaged $8.0 \mathrm{~mm}$ in depth. The silken cocoons spun by the larvae were slightly domed and were not covered with bits of carton, as they are in at least some species of the genera Mischocyttarus, Clypearia and Epipona (Jeanne, unpublished data). 
The upper comb (Fig. 3) had 288 cells in 25 rows. There were three generations of brood ${ }^{1}$ in this comb. Two cells in the center of the comb contained eggs of the third generation, and next to these were five second-generation pupae. Surrounding these were 58 cells containing meconia and second-generation larvae, decreasing in age away from the center of the comb, and they in turn were surrounded by a ring of 90 cells containing meconia and secondgeneration eggs. Thirteen empty cells were scattered throughout these egg and larval cells. Around the second-generation egg cells were the remaining brood of the first generation: 92 pupae surrounded by 25 larvae and three eggs.

The lower comb consisted of 52 cells. This comb was apparently younger than the upper one, and contained only two generations. The oldest part of this comb appeared to be at the proximal end (end nearest the leaf petiole), where the end cell contained a meconium and an egg, probably of the second generation. Moving distally along the comb, there were 37 pupae, three larvae and one egg of the first generation, with no empty cells.

The entire nest, therefore, contained 97 eggs, 86 larvae, I34 pupae and 13 empty cells for a total of 330 cells. Richards and Richards (195I) estimate the ages of nests in developmental units, one unit being the developmental period from egg to adult. By this measure the nest was just over two developmental units old.

There are three species of Pseudochartergus, and the nest of one, $P$. chartergoides, has previously been described by $\mathrm{R}$. von Ihering (I904), A. Ducke (I905) and J. Bequaert (1938). It consists of a single, usually elongate comb, attached by pillars to the underside of a banana-like leaf or a palm leaflet. The comb is enclosed by a second leaf or leaflet fastened under the first with a secretion similar to that described above for $P$. fuscatus. The nest of $P$. fuscatus differs from nests of $P$. chartergoides in having a second comb, and from nests of most other vespids in that the cells of this comb open upward. To my knowledge the only recorded instance of a vespid nest with upward-opening cells is Ropalidia flavopicta javanica from Java (van der Vecht, I962).

The transparent film enclosing the nest is likewise unusual but not unique to the genus. A nest of Ropalidia opifex described by

\footnotetext{
"The term "generation of brood" as used here is defined such that the $x^{\text {th }}$ generation comprises all those brood in cells being used for the $x^{\text {th }}$ time. Since the adults of a colony may continue to add cells to the periphery of a comb that has developing brood in the center, several generations of brood may be present in a single comb at one time.
} 
van der Vecht (1962) consisted of a single comb attached by a number of pillars to the underside of a fern frond and enclosed in a "silk-like canopy resembling polythene in colour and degree of transparency" (p. 70). The photographs of this nest reveal the striking resemblance of the canopy to the film described above for $P$. fuscatus, even down to the ridged thickenings. Van der Vecht mentions, however, that the covering was "very delicate" (p. 70), whereas that of $P$. fuscatus was quite tough.

To my knowledge Pseudochartergus and Ropalidia are the only genera to enclose their nests in a transparent film. However, wasps of the genera Polistes, Mischocyttarus and probably others produce a similar substance which they apply with their mouthparts to build up the very tough petioles from which their nests are suspended (Rau, 1933; Eberhard, 1969). It is possible that these two substances have a common glandular source.

Richards and Richards (195I) classify the nest of Ps sud:char:ergus chartergoides as stelocyttarous and gymnodomous; that is, the comb is attached by petioles to the substrate and is not surrounded by an envelope. But they observed no nests in the field and apparently relied on the description written by Ducke (I910), which makes no mention of a clear film joining the leaves surrounding the nest. Bequaert (I938), however, mentions the film, and it was consistently present in the nests of $P$. chartergoides I found near Belém. Since the leaves and film form an envelope that surrounds the nest, much as do the more conventional carton envelopes of other genera, I am inclined to conclude that the nests of these two species can properly be called calyptodomous.

\section{Stelopolybia (Gymnopolybia) testacea}

This nest was collected on July 22, 1968, in rain fo-est at Fazenda Taperinha, $40 \mathrm{~km}$ east of Santarém, Pará, Brazil $\left(2^{\circ} 26^{\prime} \mathrm{S}, 54^{\circ} \wedge \mathrm{I}^{\prime} \mathrm{W}\right)$. It was discovered where it had fallen onto a footpath. The nest had been suspended about ten meters above the ground beneath a large, woody spathe of an "inaja" palm (Maximiliana reg: $a$ Mart.). This inverted spoon-shaped structure, nearly a meter in length, had

Fig. 4. The nest of Stelopolybia testacea as it lay on the ground when discovered. The supporting spathe, to the left and rear, arches over the combs, which lie stacked face up. The topmost comb, number 11, is folded back upon itself. There are numerous adult wasps on the spathe and combs.

Fig. 5. S. testacea nest reconstructed, as it would appear from beneath if the nest were in situ. The base of the spathe is at the right. The semicylindrical form of the nest is most pronounced in the older combs, at the top of the illustration. About $1 / 8$ natural size. 

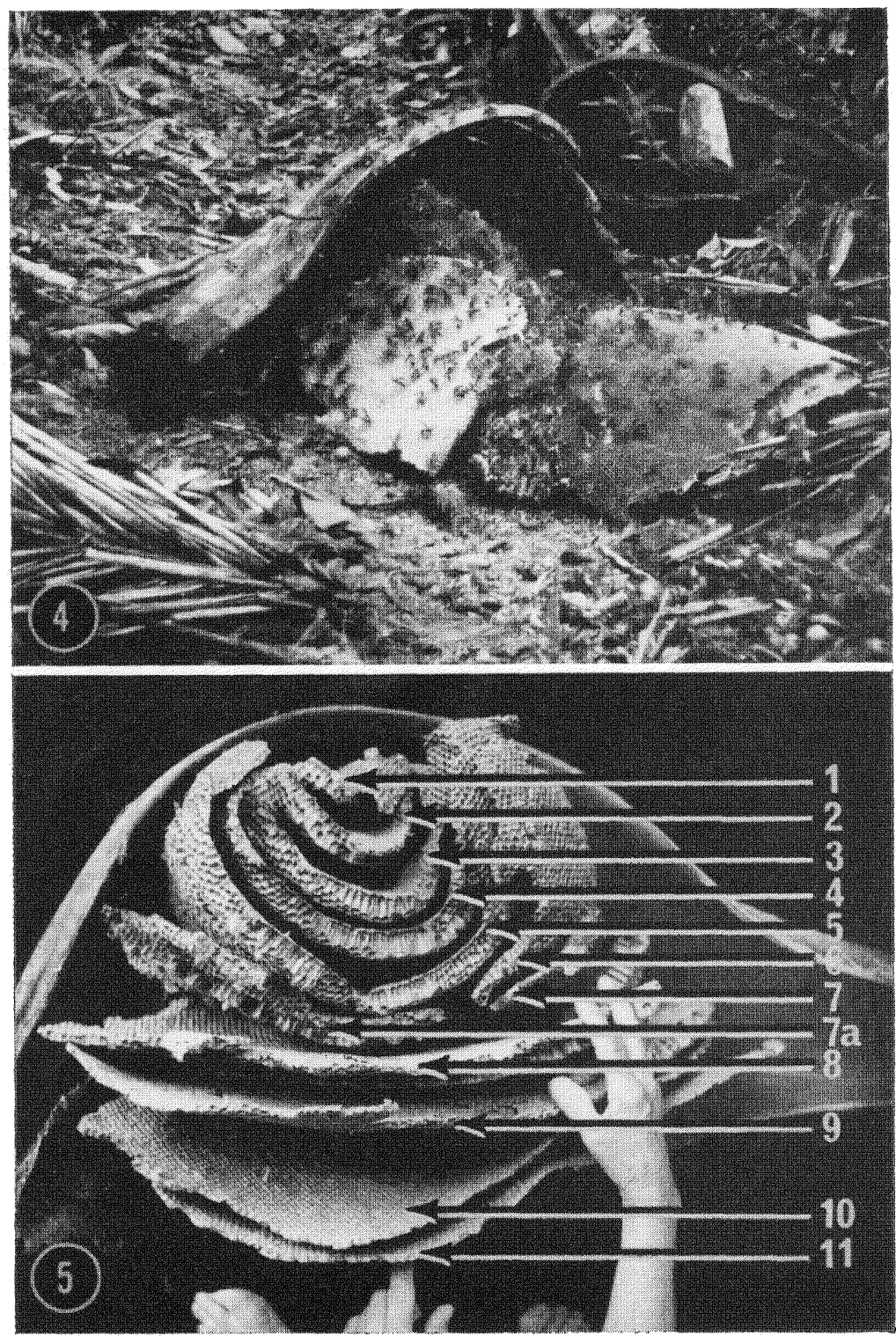
formed a natural roof over the nest, but the base of the spathe had so rotted that the weight of the nest caused it to break (Fig. 4). The nest had lain on the ground for more than a week, but the adults had not abandoned it. The fall had torn the nest away from the spathe, but the combs lay stacked on top of one another in the normal position relative to one another, so the nest could be roughly reconstructed (Fig. 5).

The nest was constructed of fine-textured carton of a uniform tan color. The cells averaged $5.9 \mathrm{~mm}$ in diameter (measured between midpoints of opposite walls) and opened on the convex sides of the combs. The silken caps of the pupal cocoons were slightly domed, and were not covered with bits of carton. The bottoms of the cells were convex, giving the backs of the combs a mammillated surface.

There were twelve combs, each hanging vertically from an edge by several pillars, and not surrounded by an envelope. The combs were constructed as concentric semi-cylinders around a vertical axis at one side of the spathe. Each comb was connected to adjacent combs by many pillars (Fig. 6). The comb nearest the central axis was the smallest and apparently was the first to have been built. Between combs 5 and 8 were three combs. Two of them, labelled 6 and 7, were at the proximal end of the nest (end nearest the base of the spathe; see Fig. 5). The third, called 7a, filled up most of the remaining space at the distal end of the nest. A vertical discontinuity between the right and left sides of combs 4 and 5 (Fig. 8) suggests that these two combs were initially composed of separate right and left portions which were fused as they were enlarged toward one another. A similar situation seemed to have occurred in the case of combs 6, 7 and $7 a$, except that $7 a$ and 7 (or 6) were never fused. The size and brood contents of each comb are given in Table I.

The presence of a meconium in a cell indicated that the cell had produced an adult. No attempt was made to determine the presence of more than one meconium in a used cell. Within a given comb the brood decreased in age from the center outwards. Comb 8

Fig. 6. Combs 4-7 of the $S$. testacea nest showing how they are interconnected by numerous pillars. About $1 / 2$ natural size.

Fig. 7. Comb 3 of the S. testacea nest in position on the spathe, combs 4-11 removed. The white caps of the pupal cocoons cover most of the central cells.

In Figs. 7-9 the combs are shown in an upside down position; that is, the edge from which each comb is suspended from the spathe is at the bottom of the figure. The proximal end of each comb is to the right. 

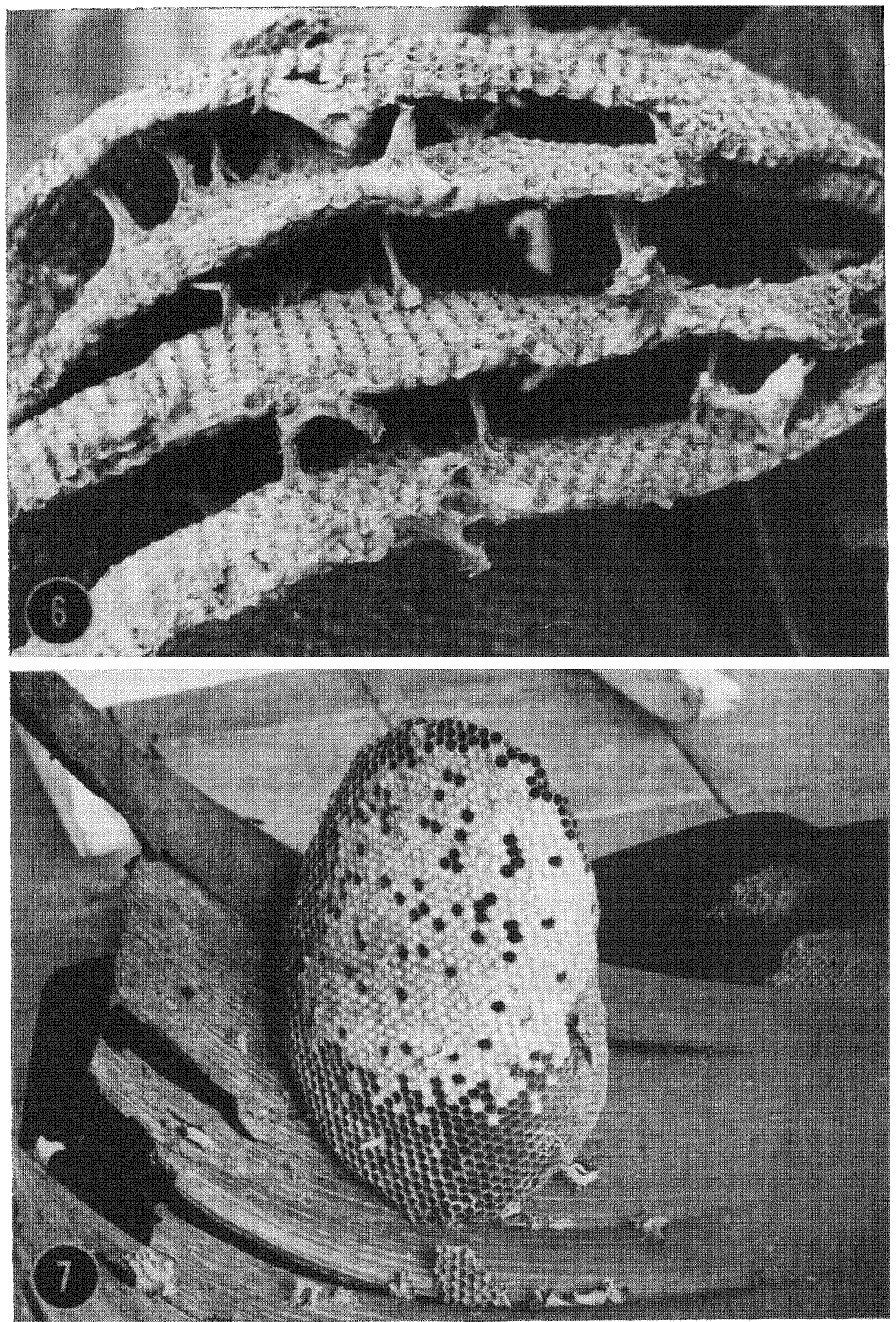
showed this most clearly (Fig. 9). In comb 3 (Fig. 7), since the empty cells peripheral to the pupae had meconia, at least one complete generation of brood had been produced by this comb, and the pupae present belonged to a second generation. Since combs I and 2 were probably older than 3 , it can be assumed that comb I had produced two complete generations and that the pupae of comb 2 were vestiges of the second generation. Comb 4 was then probably of approximately the same age as 3 , and its pupae were of the second generation. Comb 5 had probably contained larvae of the second generation before the nest fell. Comb $7 \mathrm{a}$ was probably only slightly younger than 5, and had larvae of the second generation. Combs 6 and 7 had not produced any adults. Either they were constructed after $5,7 \mathrm{a}$ and 8 , or they were constructed in sequence and not used. Since the cells peripheral to the masses of capped cells in combs 8 and 9 (Fig. 9) were free of meconia, the pupae of these combs must have been of the first generation. Combs IO and II, free of meconia and with low cell walls, may have been empty or may have contained first-generation eggs and young larvae before the nest fell.

The entire nest contained an estimated 27,600 cells, and of these approximately 3,000 contained pupae. The nest was at least twoplus developmental units old, and possibly older. That is, it is possible that combs I through 7 a had produced more than two generations of brood, and that comb 7a may have produced at least one full generation before combs 8 through i I were even constructed.

It is interesting that nearly all the brood were in pupal stages, and that eggs and younger larvae were totally lacking. It may be that the fall of the nest caused the adults to remove the younger brood in order to devote all their efforts to rearing the older brood to maturity. Or it is possible that the fall of the nest had nothing to do with it, and that the colony was mature and was getting ready to swarm. In Panama, Rau ( 1933) collected an apparently mature colony of Stelopolybia pallipes var. bequaerti, the brood of which

Fig. 8. Combs 5, 6 and 7 of the S. testacea nest in position on the spathe, with combs 7a-11 removed. The discontinuity in the rows of cells runs up the middle of comb 5. Combs 6 and 7 are nearly the same size and cover the right side of comb 5 .

Fig. 9. Comb 8 of the $S$. testacea nest. The brood decreases in age from center outward. The empty cells in the center had all produced adults, and at the time the nest was collected adults were emerging from the innermost capped cells (note torn cell caps), indicating that these contained the oldest pupae. Newly-emerged adults can be seen resting on the comb. 

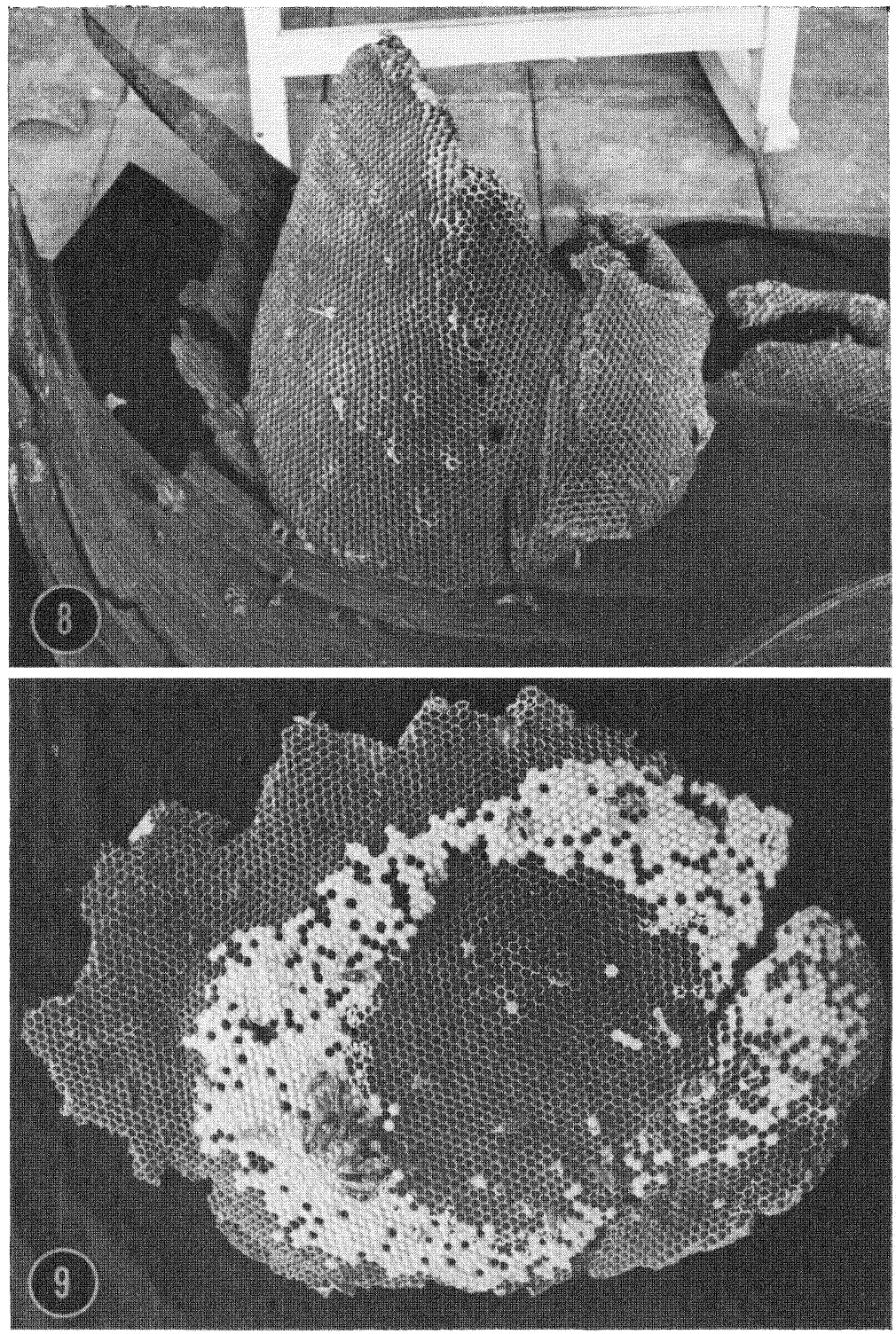
TABLE I

\begin{tabular}{|c|c|c|c|c|c|}
\hline Comb & $\begin{array}{l}\text { Dime } \\
\text { (in } \\
\text { width }\end{array}$ & $\begin{array}{l}\text { nsions } \\
\text { ells) } \\
\text { length }\end{array}$ & $\begin{array}{l}\text { Est. no. } \\
\text { of cells }\end{array}$ & Brood & Meconia \\
\hline 1 & 26 & 16 & 300 & none & most cells \\
\hline 2 & 40 & 40 & 1200 & $\begin{array}{l}\text { a few pupae in } \\
\text { center }\end{array}$ & most cells \\
\hline 3 & 41 & 50 & 1500 & $\begin{array}{l}\text { large mass of pupae } \\
\text { and a few mature } \\
\text { larvae in center }\end{array}$ & most cells \\
\hline 4 & 80 & 60 & 3600 & $\begin{array}{l}\text { large mass of pupae } \\
\text { and a few mature } \\
\text { larvae in center }\end{array}$ & most cells \\
\hline 5 & 80 & 60 & 3600 & none & most cells \\
\hline 6 & 35 & 40 & 1100 & none & none \\
\hline 7 & 35 & 40 & 1100 & none & none \\
\hline $7 \mathrm{a}$ & 60 & 45 & 2100 & none & most cells \\
\hline 8 & 90 & 36 & 2500 & ring of pupae & $\begin{array}{l}\text { most cells inside } \\
\text { ring, none } \\
\text { outside ring }\end{array}$ \\
\hline 9 & 90 & 36 & 2500 & $\begin{array}{l}\text { large mass of pupae } \\
\text { and a few mature } \\
\text { larvae in center }\end{array}$ & none \\
\hline 10 & 85 & 55 & 3700 & none & none \\
\hline 11 & 100 & 55 & 4400 & none & none \\
\hline
\end{tabular}

were almost all pupae. Rau concluded that the colony was about to swarm.

The $S$. testacea colony was collected at night, when all the adults were presumably on the nest, and very few escaped during collection, so the 6,466 adults taken represent close to the total population of the colony at the time. However, due to the disruption caused when the nest fell, it is possible that the population before the fall was significantly greater.

A sample of 1,626 wasps was examined and found to comprise I I 5 males $(7.1 \%)$ and I5II females $(92.9 \%)$. During the day after the nest was collected one male and three females emerged from combs 3 and 4, and one male and 32 females emerged from combs 8 and 9. This indicates that males are reared in both younger and older portions of the nest. During the four days following collection of the nest a total of 422 adults emerged from all combs, and of these $2 \mathrm{O}(4.7 \%)$ were males and $402(95.3 \%)$ were females.

The fourteen species of Stelopolybia, all neotropical, fall into two subgenera, Angiopolybia and Gymnopolybia. The nests of two of the three species of subgenus Angiopolybia have been described (see 
Richards and Richards, 195I, and the references they cite), and both are stelocyttarous, rectinidal and calyptodomous, meaning the combs are suspended horizontally one below the other by pillars and are surrounded by an envelope.

The nests of six of the eleven species of subgenus Gymnopolybia are known, though adequate descriptions seem to exist for only four. All are stelocyttarous and gymnodomous, that is the combs are suspended by pillars and are not surrounded by an envelope. They are built in hollow trees or other sheltered places. The architecture of the $S$. (G.) testacea nest described here most closely resembles that of $S$. (G.) pallipes and $S$. (G.) cajennensis, which build semi-cylindrical interconnected combs hung vertically by their edges (Richards and Richards, I95 I, and cited references). S. (G.) vicina and $S$. (G.) meridionalis hang their combs horizontally, each one suspended from the one above by many paper pillars ( $R$. von Ihering, 1904).

The marked curving of the combs around a vertical axis seems to be the rule in $S$. pallipes, cajennensis and probably testacea as well. The effect is to stiffen the combs, making them much less likely to bend along a horizontal axis. Such a configuration may have been evolved to reduce nest damage due to wind when the nests are constructed in exposed situations, as was the nest of $S$. testacea.

As far as I am aware, the 6,466 adults of this colony make it the most populous colony of Stelopolybia ever collected, and it is among the largest colonies of any neotropical wasp. The above-mentioned colony of $S$. pallipes var. bequaerti collected by Rau had 1965 adults, and Richards and Richards (195I) describe taking a nest of $S$. fulvo-fasciata in Guyana with I409 adults (many more escaped). Eight colonies of $S$. pallens collected by Richards and Richards in Guyana contained between 25 and 390 adults each. The largest colony of any New World polistine wasp on record is one of Brachygastra mellifica collected near Brownsville, Texas, with about 15,000 individuals (Schwarz, 1929). Naumann (1968) reported seeing a colony of the same species with about I0,000 adults (no locality was given). Richards and Richards report taking a nest of Protopolybia pumila in Guyana with 7,087 individuals.

These figures, of course, do not necessarily indicate maximum mature colony size. If the colony was collected during the day, many foragers may have been gone from the nest. In many cases in the literature a good portion of the adult population escaped during collection and were not counted. More fundamentally, the popula- 
tion size depends upon the age of the colony. For these reasons the figures cited can be used as only a very approximate guide to the mature size of a "typical" colony of each species.

\section{Note on a parasite of Stelopolybia testacea}

On the second day following collection of the $\mathcal{S}$. testacea nest, a parasite emerged from one of the capped cells of comb 8. It has been tentatively identified ${ }^{2}$ as Nomadina cisandina (Schulz) (Hymenoptera, Trigonalidae). It superficially resembled its host in form and color except that it was slightly smaller in size, had a relatively smaller head, and lacked the black markings on the gastral segments. The empty pupal skin of the $S$. testacea host remained between the cocoon of the parasite and the wall of the paper cell. The cap of the cell appeared normal and was evidently spun by the $S$. testacea larva. It is interesting that the adult parasite emerged from a section of comb from which adult $S$. testacea were emerging at that time. A second adult parasite of the same species was found on the nest several days later.

Other species of Trigonalidae are known to be parasitic on social Vespidae. Bertoni (I9II) has recorded Seminota marginata from species of Apoica and Polistes, and $S$. depressa from Polistes. Clausen (1929) has recorded Nomadina cisandina from Polybia, Seminota mejicana from Parachartergus, and Pseudogonalos hahni and Bareogonalos canadensis from Vespa.

\section{Acknowledgements}

I gratefully acknowledge Dr. Paulo E. Vanzolini and Dr. Dalcy Albuquerque for helping to make possible my stay at the Museu Goeldi in Belém; Senhoras Erica and Violeta Hagmann for the generous hospitality shown me during my stay at Taperinha and for help in collecting the nest of S. testacea; Mrs. Sally Landry for executing the drawing in Fig. I; and Dr. E. O. Wilson, Dr. Wm. Eberhard and Miss Nancy Lind for critically reading the manuscript. The field work was supported by NSF Predoctoral Fellowships and by grants from the Evolutionary Biology fund at Harvard. Financial support was also received from the National Science Foundation (Grant No. GB 7734, E. O. Wilson, Sponsor).

${ }^{2}$ By I. H. H. Yarrow, British Museum (Natural History). 
BequaERT, J.

\section{REFERENCes}

1938. A new Charterginus from Costa Rica, with notes on Charterginus, Pseudochartergus, Chartergus, Pseudopolybia, Epipona and Tatua (Hymenoptera, Vespidae). Rev. de Entomologia, 9(1):99-116.

BerToni, A. DE

1911. Contribución á la biología de las avispas y abejas del Paraguay. An. Mus. nac. Buenos Aires, 22: 97-146.

Clausen, Curtis P.

1929. Biological studies on Poecilogonalos thwaitesii (Westw.), parasitic in the cocoons of Henicopilus (Hymenoptera, Trigonalidae). Proc. Ent. Soc. Wash., $31(4)$ : 67-79.

DUCKe, ADOLPH

1905. Sobre as vespidas sociaes do Pará. ( $1^{\circ}$ Supplemento). Bol. Mus. Goeldi, 4: 652-698.

1910. Révision des guêpes sociales polygames d'Amérique. Ann. Mus. Nat. Hungarici, 8 : 449-544.

1914. Ueber Phylogenie und Klassifikation der sozialer Vespiden. Zool. Jahrb. (Syst.), 36: 303-330.

Eberhard, Mary Jane West

1969. The social biology of polistine wasps. Misc. Publ. Mus. Zool. Univ. Michigan, No. 140, Ann Arbor. $101 \mathrm{pp}$.

IHERING, R. VON

1904. As vespas sociaes do Brazil. Rev. Mus. Paulista, 6: 97-309.

Naumann, Martin G.

1968. A revision of the genus Brachygastra (Hymenoptera, Vespidae). Univ. Kansas Sci. Bull., 47: 929-1003.

Rav, Phil

1933. The jungle bees and wasps of Barro Colorado Island (with notes on other insects). Kirkwood, Mo.

Richards, O. W. ANd M. J. Richards

1951. Observations on the social wasps of South America (Hymenoptera, Vespidae). Trans. R. ent. Soc. London, 102: 1-120.

Saussure, Henri De

1853-8. Monographie des guêpes sociales, ou de la tribu des Vespiens. Paris \& Geneva.

SChWARZ, H. F.

1929. Honey wasps. Natural History, 29(4): 421-426.

VECHT, J. VAN DER

1962. The Indo-Australian species of the genus Ropalidia (Icaria) (Hymenoptera, Vespidae) (Second Part). Zool. Verh., Leiden, 57: 1-72. 

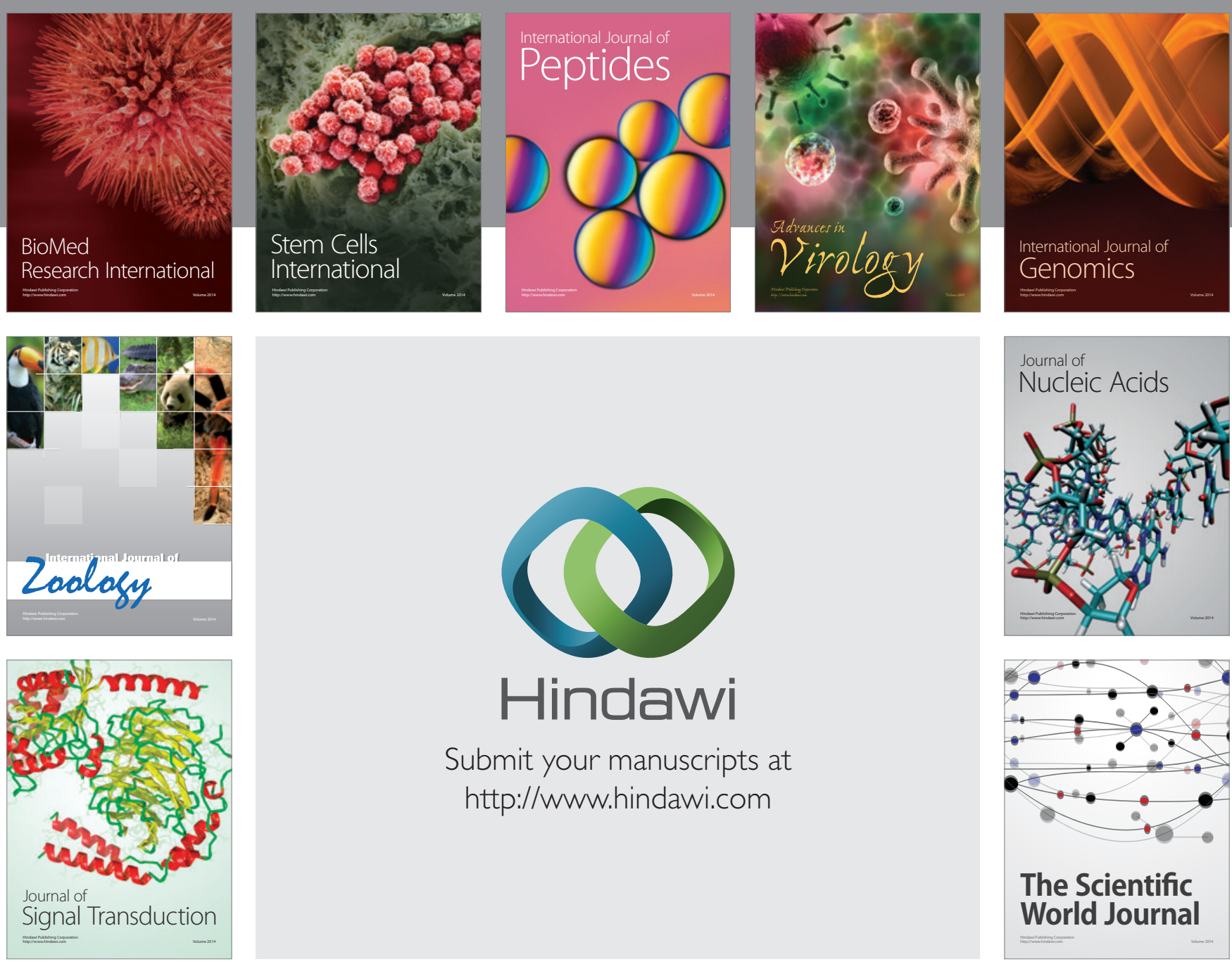

Submit your manuscripts at

http://www.hindawi.com
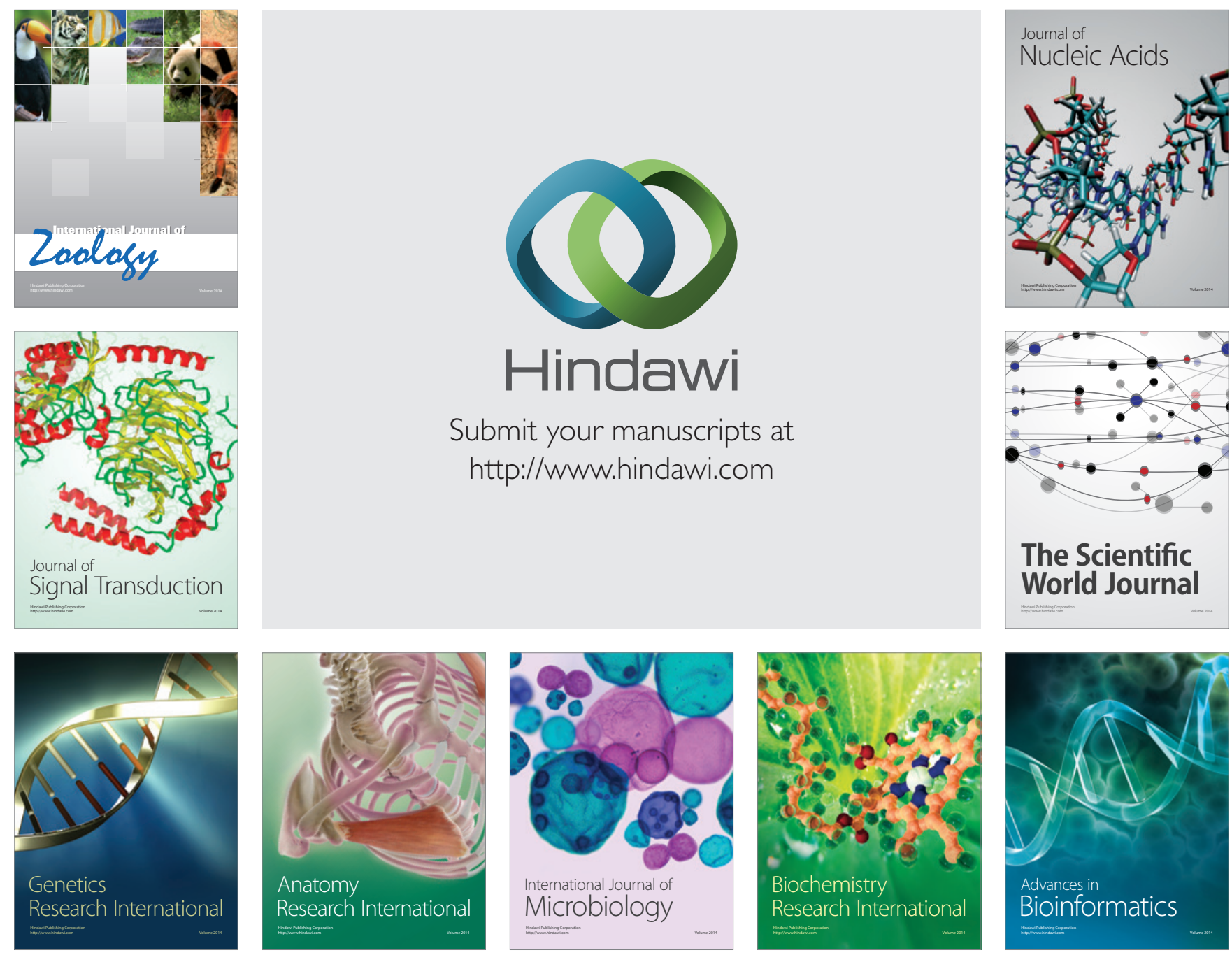

The Scientific World Journal
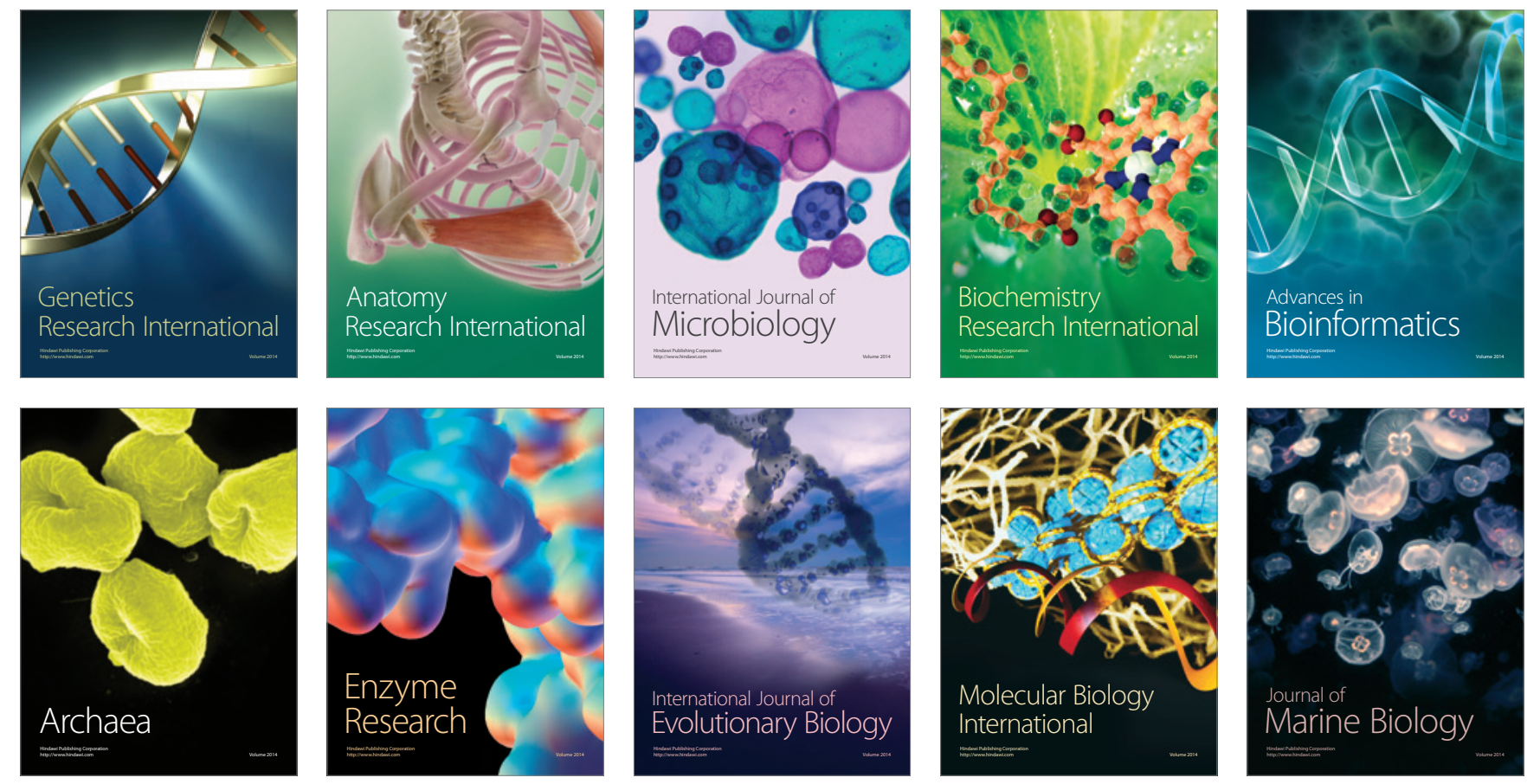